\title{
DECOLOURIZATION OF YAMUNA WATER USING PEANUT HULL IN PACKED BED REACTOR
}

\author{
Varsha Panchal ${ }^{1}$, Arpita Ghosh ${ }^{2}$, Pushpa C. Tomar ${ }^{1, *}$ and Shilpa S. \\ Chapadgaonkar ${ }^{1}$ \\ ${ }^{1}$ Department of Biotechnology, Manav Rachna International Institute Research and Studies, \\ 121001(Faridabad) India, \\ ${ }^{2}$ Indian Institute of Management Sirmaur, 173025(Paonta Sahib, Himachal Pradesh) India \\ *E-mail: pushpa.fet@mriu.edu.in
}

\begin{abstract}
Water pollution is a global concern that has led to a scarcity of usable water and has caused monumental damage to the water ecosystems. Yamuna River is known to be one of the most polluted rivers in India owing to unrestricted direct discharge of sewage and effluent into it. The holy river Yamuna has become so polluted that water practically looks grey-black and has a repulsive stinking smell to it. The latest reports, the BOD level of Yamuna water reached $93 \mathrm{mg} \backslash \mathrm{L}$ and the TDS level reached $1500 \mathrm{mg} \backslash \mathrm{L}$ (highest in the stretch of Yamuna near Nizamuddin bridge). This needs to be remedied by introducing efficient and cost-effective strategies for the control of contaminants ideally at the point of generation or before discharge. Pollutants like heavy metals, pesticides, dyes,etc. make water toxic resulting in serious health effects on consumption. The present study was undertaken to study the efficiency of peanut hull for the removal of color from the water of the river Yamuna. Peanut hull is an abundantly available agrowaste material that can be obtained all over India and is harmless to the environment. The study was carried out in a packed bed reactor packed with peanut hull powder. Raw peanut hull demonstrated excellent color removal potential in the study. Then, raw peanut hull was chemically modified using $2 \%$ formaldehyde $(\mathrm{HCHO})$ which stabilized the material and increased reusability and efficiency. The bioreactor was constructed and was packed evenly with a crushed peanut hull. Yamuna water was applied drop-wise and recycled through the reactor continuously for 10 hours. After about 5 cycles the approximately about $97 \%$ of color removal was obtained in the first run. The second stage was performed with chemically modified crushed peanut hull which further increases the efficiency and shows up to $100 \%$ removal of color from the Yamuna river. This technique can also be employed for the decolorization of wastewater effluent from paper industries, food industries, and textile industries. Moreover, in this way, the dual purpose of wastewater treatment, as well as sustainable use of solid waste, can be achieved.

Keywords: Contaminants, Decolourization, Packed Bed Reactor, Peanut Hull, Sustainability, Wastewater Treatment, Yamuna Water.
\end{abstract}

(C) RASĀYAN. All rights reserved

\section{INTRODUCTION}

Water is the most precious resource in life. The rivers are an invaluable source of water, but drastic industrialization and urbanization have to lead to high water pollution ${ }^{1,2}$. Yamuna river is known to be the most polluted river in the Delhi- NCR region of India owing to the discharge of effluents from numerous industries into it. Moreover, domestic activities bathing, cloth washing, cattle wadding and domestic sewage add to the pollution. Many effluents lead to eutrophication resulting in the growth of harmful microorganisms. These harmful microorganisms are responsible for significant health risks such as allergies, eye irritation, skin infections, effect digestive tract, mutagenic disease and cancer ${ }^{3,4}$. This uncontrolled pollution restricts photosynthesis and affects the aquatic ecosystem also changes the natural color of Yamuna river water to dark grey black ${ }^{5}$. The central pollution board (CPCB), Central water commission (CWC), Delhi pollution control committee (DPCC), State pollution control board (SPCB) monitors 19 locations of Yamuna river continuously and it is reported that water of Yamuna is unfit for drinking purpose ${ }^{6}$. A stretch of Nizamuddin Bridge of Delhi found that BOD and COD levelsapproached $93 \mathrm{mg} / 1$ and $155 \mathrm{mg} / 1$ respectively which are much higher than compared to permissible level ${ }^{7}$. The

Rasayan J. Chem., 13(2), 949-954(2020)

http://dx.doi.org/10.31788/RJC.2020.1325404

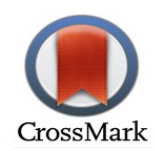


dissolved organic carbon (DOC) of Yamuna water ranges between 4.0-6.8mg/1, color unit 40-65 and chlorine removed color causing chemicals are up to $78 \%{ }^{8}$.

Considering the nationwide scarcity of water particularly, Delhi-NCR urgent measures to clean the Yamuna are required.The methods presently being employed have not been much fruitful ${ }^{9}$. Moreover, many methods are too costly to be feasible. The use of agro-waste for water treatment is an attractive emerging area where two problems of solid waste management and wastewater treatment can be solved together. Treatment via agro-waste material of color causing compounds from the river has lots of benefits. It is a cost-effective process, doesn't produce any sludge, easy to implement and an eco-friendly process. By using agro-waste products sustainability of solid waste could be achieved. Several types of agro-waste materials such as Rice husk, Bagasse, Peat, Bamboo, Date pits, Palm tree waste, Coconut husk and Tea can be used to treat effluents that contain different dyes ${ }^{10}$. Agro waste materials adsorb and absorb several pollutants. Moreover, different types of enzymes present in waste material can result in the removal of coloring (Table-1). Treatment via agro-waste material of color causing compounds from the river has lots of benefits. It is a cost-effective process, doesn't produce any sludge, easy to implement and an eco-friendly process. By using agro-waste products sustainability of solid waste could be achieved.

Table-1: Different Agro-waste Reported For Efficient Removal of Dyes

\begin{tabular}{c|c|c|c}
\hline Agro-waste (Adsorbent) & Dye Name & \% Removal Range & References \\
\hline Activated Rice Husk & Acid Yellow 36 & $45-80$ & 12 \\
\hline Fly Ash & Methylene Blue & $36-45$ & 13 \\
\hline Modified Alumina & Crystal Violet & $20-80$ & 14 \\
\hline Kaolin & Crystal Violet & $65-95$ & 15 \\
\hline Pine Leaves & Methylene Blue & $20-80$ & 16 \\
\hline Tobacco Stem Ash & Methylene Blue & $60-81$ &
\end{tabular}

In the present study, peanut hulls were used to remove color causing compounds from the Yamuna river. Peanut hulls are easily available agro-waste. So, it is a cost-effective process. In a previous study,the Peanut hull has shown high efficiency to remove different dyes such as safranin-o, methylene blue, neutral red, brilliant cresyl blue ${ }^{17}$. Peanut hull has different structural components such as lignin $(28.8 \%)$, cellulose $(37 \%)$, carbohydrates $(25 \%)$ and protein $(8.2 \%)$ which may be responsible for absorption of coloring agents.

\section{Preparation of Biosorbent Sample}

\section{EXPERIMENTAL}

Peanut hull was collected from the local Faridabad market. Peanut hull waste (PHW) was rinsed with distilled water 2-3 times to remove dirt and impurities. Washed PHW was dried in hot air. PHW was chemically modified overnight with formaldehyde solution $(2 \% \mathrm{v} / \mathrm{v})$ to stabilize the adsorbent, washed to remove traces of formaldehyde and dried.

\section{Construction and Packing of Packed Bed Bioreactor}

The packed bed bioreactors used in the study was constructed using transparent plastic transparent pipe (30 $\mathrm{cm}$ length, $2.54 \mathrm{~cm}$ diameter).The reactor was packed with crushed PHW and sealed with gauze (Fig.1) The volume packed bed volume was $152.0 \mathrm{ml}$ and the mass of PHW powder used for packing the reactor was $30 \mathrm{~g}$.

\section{Water Sample}

Yamuna water sample was collected from the Delhi stretch of the Nizamuddin bridge (Shastri park). The water sample was dark grey-black with a strong foul smell.

\section{Determination of TSS}

Measurement of settle-able solids in water was carried out using a standard filter paper method. Distilled water was passed through filter paper and subsequently, the filter was dried and weighed. Then on the same filter paper, the wastewater sample was filtered. The solids retained on the filter paper were weighed and TSS was calculated using the following Eq.-1. 
RASĀYAN J. Chem.

Vol. 13 | No. 2 |949 - 954| April - June | 2020

TSS $=\frac{(\mathrm{A}-\mathrm{B}) \times 1000}{\text { Vol of sample }}$

Where, $\mathrm{A}$ is the weight of filter paper + dried residue, B is the weight of filter paper.

\section{Determination of TDS}

The TDS was determined by evaporating a known volume of sample in a china dish on a hot plate(Eq.-2): $T D S=\frac{(\mathrm{A}-\mathrm{B}) \times 1000}{\text { Vol of sample }}$

Where, $\mathrm{A}$ is the weight of dried residue + china dish, B is the weight of china dish.
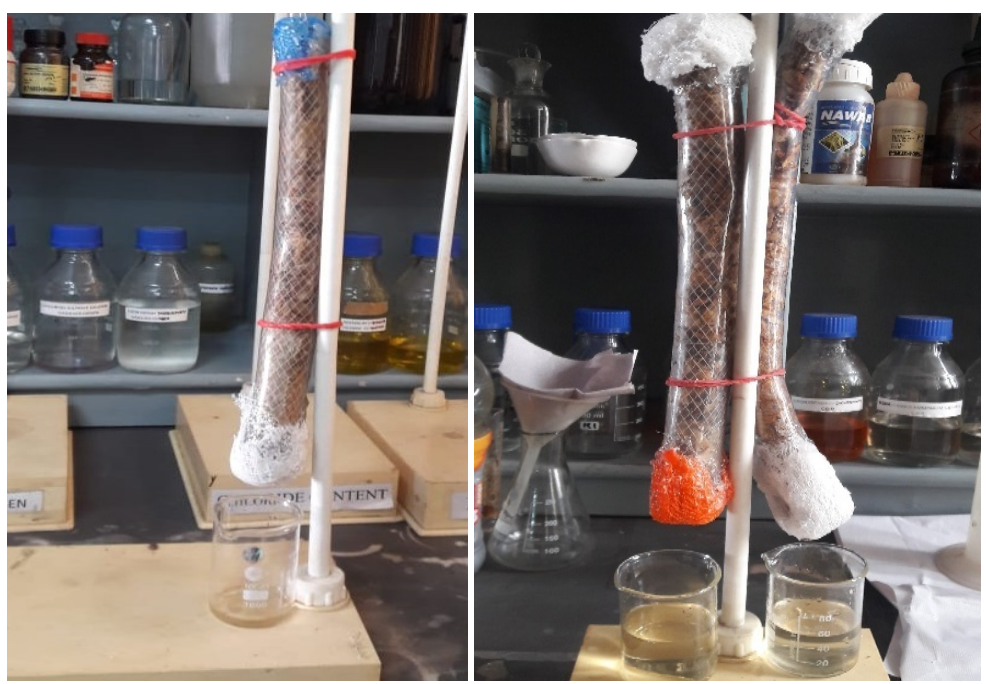

Fig.-1: Constructed Bioreactor filled with Crushed Peanut Hulls

\section{Determination of Dissolved Oxygen (DO)}

$300 \mathrm{ml}$ of wastewater sample was taken in a BOD bottle. $2 \mathrm{ml}$ of $48 \% \mathrm{w} / \mathrm{v}$ Manganese sulphatewas added to the water sample and mixed thoroughly by inverting the bottle. Subsequently, $2 \mathrm{ml}$ of alkali-iodideazide $(500 \mathrm{~g} \mathrm{NaOH}$ and $135 \mathrm{~g}$ sodium iodide dissolved in $1 \mathrm{~L}$ distilled water.10 g sodium Azide dissolved in $40 \mathrm{ml}$ distilled water with stirring. Both the solutions were mixed after cooling) solution was added to the water sample. The flocs formed were dissolved using $2 \mathrm{ml}$ of concentrated sulphuric acid. Exactly $200 \mathrm{ml}$ of the solution was poured into a new flask and titrated with $0.025 \mathrm{M}$ sodium thiosulphate until the pale yellow color was obtained. Then the starch solution was added. This led to the formation of the blue color of the starch-iodide complex. The titration was continued until the solution decolorized completely. Dissolved oxygen was calculated using the following equation:

$\frac{0.2 \times 1000 \times 0.025}{200}$

\section{RESULTS AND DISCUSSION}

Comparison of water quality parametersof Yamuna water samples before and after treatment are given in Table-2.

Table-2: Yamuna Water Quality Parameters Before and After Treatment.

\begin{tabular}{c|c|c}
\hline Parameters & Observations (Before Treatment) & Observations (After Treatment) \\
\hline Colour & Black-grey & Colorless \\
\hline Smell & Foul odor & No odor \\
\hline pH & 7.0 & 6.8 \\
\hline D.O & $0.7 \mathrm{mg} \backslash 1$ & $0.9 \mathrm{mg} \backslash 1$ \\
\hline TSS & $1000 \mathrm{mg} \backslash 1$ & $220 \mathrm{mg} \backslash 1$ \\
\hline TDS & $4140 \mathrm{mg} \backslash 1$ & $3450 \mathrm{mg} \backslash 1$ \\
\hline
\end{tabular}


RASĀYAN J. Chem.

Vol. 13 | No. 2 |949 - 954| April - June | 2020

The Colour of Yamuna River was black and grey because of organic waste, sewage, and dyes. The smell of the Yamuna river water was pungent due toexcessive pollution. Dissolve oxygen was as low as $0.7 \mathrm{mg} / \mathrm{l}$. TSS and TDS levels were very high. After treatment, these parameters showed considerable improvement.

\section{Cyclic Mode Operation of Packed Bed Reactor}

$100 \mathrm{ml}$ of Yamuna water sample was cycled through the bioreactor for 5 hours at room temperature. The sample was taken every hour. These samples were centrifuged at 2000 RPM for $10 \mathrm{~min}$ to remove suspended particles. The optical density of the water sample was determined at $620 \mathrm{~nm}$. The $\%$ removal of color from Yamuna water was calculated by the following equation:

$\% R=\frac{100 \times(\mathrm{Co}-\mathrm{Ce})}{\mathrm{Co}}$

Where, $\mathrm{R}$ is the \% removal of color compounds from the sample, Co - initial absorbance, Ce - final absorbance.

The residence time of the $100 \mathrm{ml}$ solution was $1 \mathrm{~h}$. The adsorption of colored impurities in wastewater increases with time of contact reaching saturation by $5 \mathrm{~h}$. When adsorption was continued further, the peanut hull themselves release colored compounds leading to an increase in OD. Maximum removal ofup to $97 \%$ was observed in $4 \mathrm{~h}$ of reactor operation (Fig.-2).

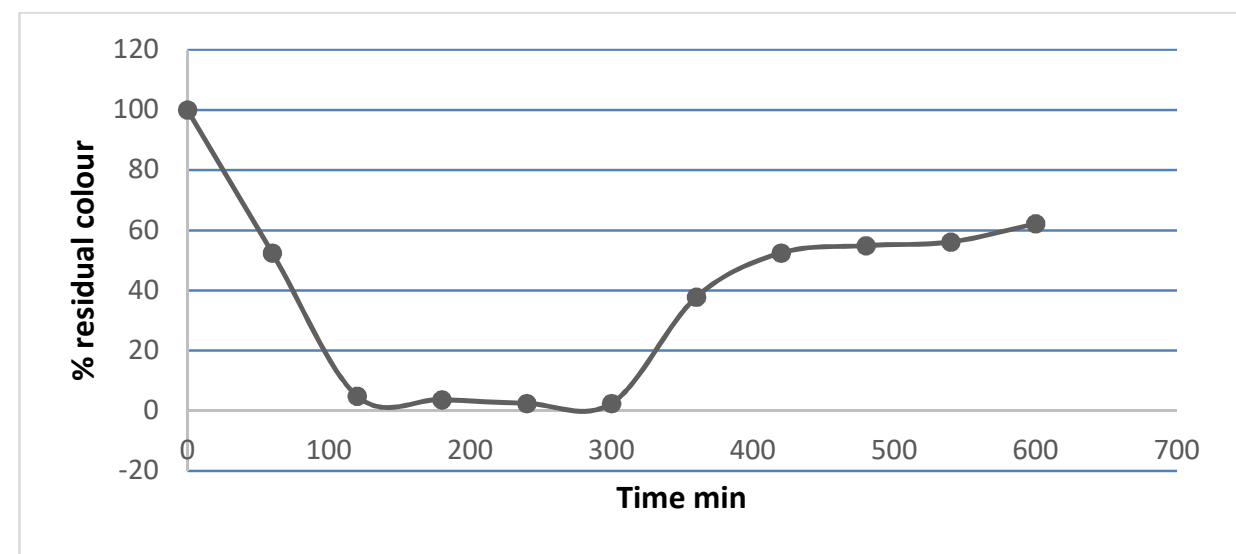

Fig.-2: Removal of Dye in Cyclic Mode

To stabilize the adsorbent, the peanut hull adsorbent was modified using formaldehyde $(2 \% \mathrm{v} / \mathrm{v})$ and used for water treatment. Color removal of Yamuna water through modified peanut hulls showed removal up to $100 \%$ removal in 6 cycles (Fig.-3).

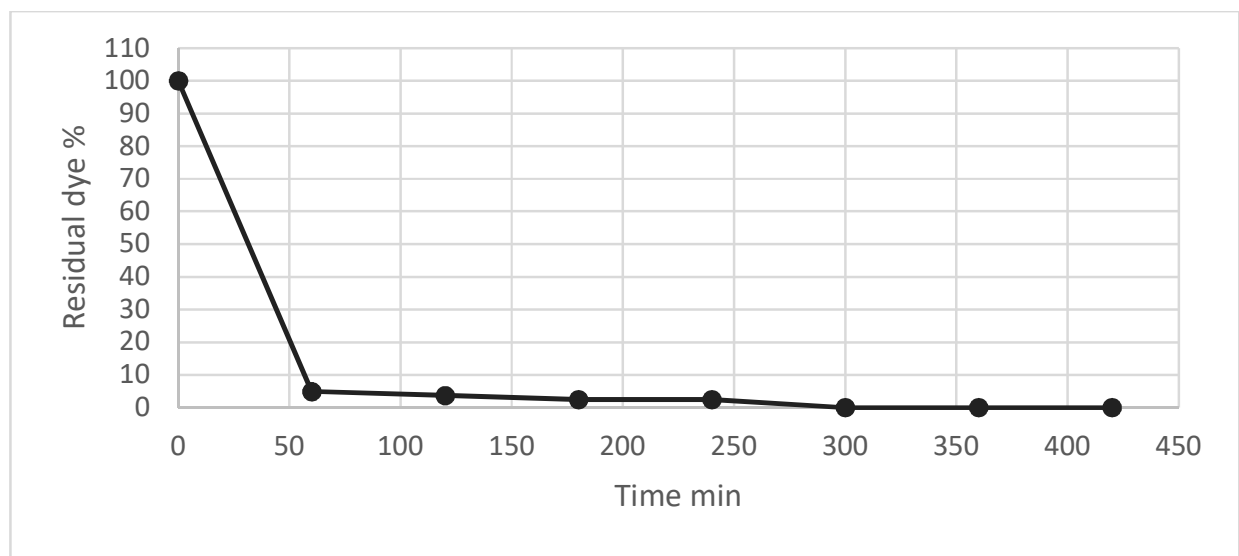

Fig.-3: Decolourization using Modified Adsorbent. 
RASĀYAN J. Chem.

Vol. 13 | No. 2 |949 - 954| April - June | 2020

\section{Non-cyclic Mode}

In the non-cyclic mode in $50 \mathrm{ml}$ of Yamuna water was cycled through bioreactor having modified peanut hulls each hour. The total volume of treated water was $750 \mathrm{ml}$. The process was continued for $15 \mathrm{~h}$. The removal efficiency obtained was between 98 in the first 8 h however the efficiency of the reactor falls after the $9^{\text {th }}$ hour. Thus it can be concluded that a modified peanut hull has the excellent capability for the treatment of wastewater (Fig.-4).

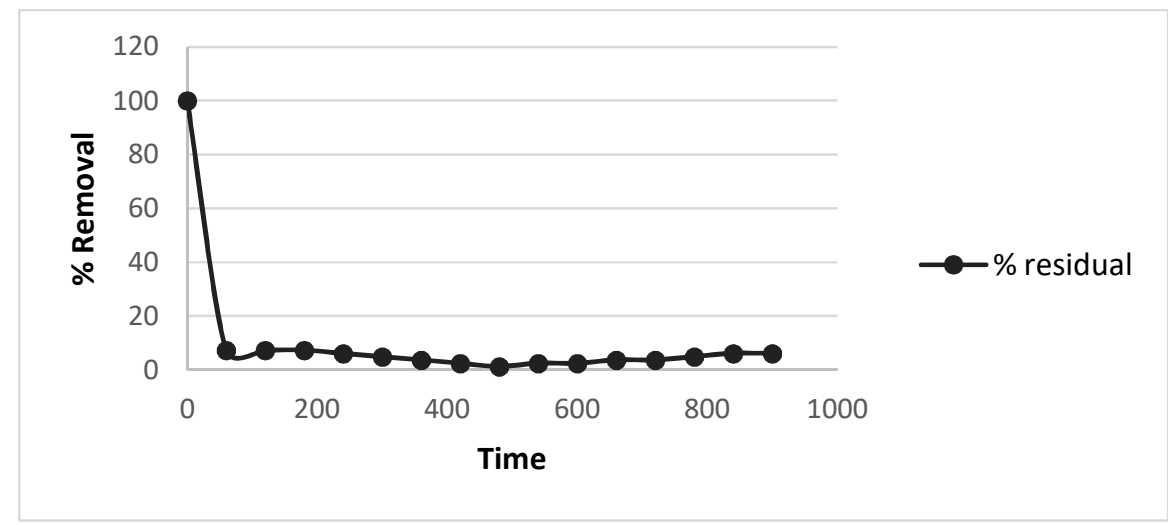

Fig.-4: Dye Decolorization in Non-cyclic Mode.

\section{CONCLUSION}

In this study, the main objective was to treat Yamuna water and improve the quality parameters. Especially, the objective was to remove coloring compounds present in the River water. Modified peanut hull showed excellent adsorbent properties for adsorption of impurities from water. The decolorization efficiency of $100 \%$ was obtained with a modified peanut hull as adsorbent. Moreover, in non-cyclic mode, the reactor $750 \mathrm{ml}$ of water could be effectively treated in $15 \mathrm{~h}$ of operation. Peanut hullthus have excellent properties to be used as an adsorbent for the treatment of River water leading to considerable improvement in quality parameters like color, odor, and dissolved oxygen. Thus, the present work makes a strong case for the effectiveness of peanut hull as bio-adsorbent for dye decolorization of wastewater.

\section{REFERENCES}

1. S. K. Sharma, R. Sanghi, A. Mudhoo, 2012, Green Practices to Save Our Precious Water Resource, Sanjay K. Sharma and Rashmi Sanghi (Eds.), in: Advances in Water Treatment and Pollution Prevention, Springer Dordrecht Heidelberg, New York, London, pp. 1-36, DOI:10.1007/978-94-0074204-8_1

2. S. K. Sharma, R. Sanghi, Waste Water Reuse and Management, Prevention, Springer Dordrecht Heidelberg, New York, London, 2013, DOI:10.1007/978-94-007-4942-9

3. C. Anand, P. Akolkar, R. Chakrabarti, Journal of Environmental Biology, 27(1), 97(2006).

4. D. Malik, S. Singh, J. Thakur, R. Kishore, A. Kapur, S. Nijhawan, International Journal of Science And Research, 3(6), 1076(2014).

5. P. K. Mutiyar, A. K. Mittal, Environmental Monitoring And Assessment, 186(1), 541(2014), DOI: 10.1007/s10661-013-3398-6

6. D. Malik, S. Singh, J. Thakur, R. K. Singh, A. Kaur, S. Nijhawan, International Journal Of Current Microbiology and Applied Sciences, 3(10), 856(2014).

7. M. A. Kumar, Journal of Water Resource And Protection, 2(5), 489(2010), DOI: $10.4236 /$ jwarp. 2010.25056

8. P. Singh, P. Kumar, I. Mehrotra, T. Grischek, Journal of Environmental Management, 91(5), 1055(2010), DOI:10.1016/j.jenvman.2009.11.013

9. N. Sato, T. Okubo, T. Onodera, A. Ohashi, H. Harada, Journal of Environmental Management, 80(3), 198(2006), DOI:10.1016/j.jenvman.2005.08.025 
RASĀYAN J. Chem.

Vol. 13 | No. 2 |949 - 954| April - June | 2020

10. P. Hadi, S. K. Sharma, G. McKay, 2015, Removal of Dyes From Effluents Using Biowaste-Derived Adsorbents, in: Sanjay K. Sharma (Ed.), Green Chemistry for Dyes Removal from Wastewater: Research Trends and Applications, Scrivener Publishing LLC, pp. 139-201.

11. H. I. Maarof, B. H. Hameed, A. L. Ahmad, Proceedings International Conference on Chemical and Bioprocess Engineering, 111(2003).

12. K. V. Kumar, V. Ramamurthi, S. Sivanesan, Journal Of Colloid And Interface Science, 284(1) 14(2005), DOI: 10.1016/j.jcis.2004.09.063

13. A. Adak, M. Bandyopadhyay, A. Pal, Separation And Purification Technology, 44(2), 139(2005), DOI:10.1016/j.seppur.2005.01.002

14. B. K. Nandi, A. Goswami, A. K. Das, B. Mondal, M. K. Purkait, Separation Science and Technology, 43(6), 1382(2008), DOI: 10.1080/01496390701885331

15. M. T. Yagub, T. K. Sen, H. M. Ang, Water, Air, and Soil Pollution, 223(8), 5267(2012), DOI: $10.1007 / \mathrm{s} 11270-012-1277-3$

16. R. K. Ghosh, D. D. Reddy, Water, Air, \& Soil Pollution, 224(6), 1582(2013), DOI:10.1007/s11270013-1582-5

17. R. Gong, M. Li, C. Yang, Y. Sun, J. Chen, Journal of Hazardous Materials, 121(1-3), 247(2005), DOI: 10.1016/j.jhazmat.2005.01.029

[RJC-5404/2019] 